Impact Factor: 4.845(SJIF) Research Journal Of English (RJOE) Vol-5, Issue-2, 2020

www.rjoe.org.in An International Peer-Reviewed English Journal

ISSN: 2456-2696

Indexed in: International Citation Indexing (ICI), International Scientific Indexing (ISI), Directory of Research Journal Indexing (DRJI) Google Scholar \& Cosmos.

\title{
ETHICO-SOCIAL VIEWS OF CHETAN BHAGAT: A CRITICAL ANALYSIS
}

\author{
Prof Vikas Sharma ${ }^{1}$ \\ D.Lit. \\ Department of English \\ C.C.S. University, Meerut \\ Sadma $^{2}$ \\ Research Scholar \\ Department of English \\ C.C.S. University, Meerut
}

\begin{abstract}
Chetan Bhagat has been admired by almost all his readers of $21^{\text {st }}$ century as he deals with various social, economic, political and ethical issues of the new society. As an economist he is quite worried about poverty and economic backwardness of Indian people. As a bold person he resigned his job as a banker and became a writer to bring 'change' in every field of life. He encourages the young men and women to work hard for the bright future of society and only means for real success are intelligence, imagination, self-confidence, patience in times of failure, team spirit, self-control, innovative thoughts, communal harmony etc. Each novel deals with several conflicts in the manner of Henrick Ibsen, G.B. Shaw, Henry Fielding, Charles Dickens etc. Of course, he supports the theory of art for morality. Each novel has a serious socio-ethical purpose and this paper concentrates upon the same.
\end{abstract}

Keywords: Social reconstruction, economic regeneration, perspective, persistence, temperance.

\section{Introduction:}

As an artist Chetan Bhagat does not follow the pattern of R.K. Narayan and Bhabani Bhattacharya as these two novelists overloaded their novels with references to ancient Indian classics. He knows his limitations and hence writes on the necessities and aspirations of modern young men and women. It is true that he deals with the economic hardships of Alok's family in details in Five Points Someone. Yet his focus is primarily upon the pattern of traditional engineering education that has lost its utility today to a great extent. Yet he does not accept total change in the pattern and does not hate the weekly assignments, monthly seminars, quiz programmes, viva-voce at the end of major examination. Of course, he advises 
Impact Factor: 4.845(SJIF) Research Journal Of English (RJOE) Vol-5, Issue-2, 2020

www.rjoe.org.in An International Peer-Reviewed English Journal

ISSN: 2456-2696

Indexed in: International Citation Indexing (ICI), International Scientific Indexing (ISI), Directory of Research Journal Indexing (DRJI) Google Scholar \& Cosmos.

the new breed of engineering students to be practical in their approach to education. Too much liberty can't be granted to them in the name of C2D as students don't have the ability and power to control the total system of I.I.T. or any private engineering college. It is well known that student unions were unknown in medical and engineering colleges upto 1990.

Through Ryan Chetan Bhagat aptly asserts that students should be inspired to be creative and innovative in their thoughts and the worthy professors ought not to impose their traditional thoughts upto their students. He aptly says that the senior professors ought to contribute research papers in their subject and due emphasis should be attached to research and development every year. It is called 'input' and 'output' system. There ought to be no stagnation in the field of knowledge and new knowledge replaces old thoughts within weeks now. Then it is necessary that there should be arrangement of interdisciplinary seminars and conferences every year and professors and students ought to participate in them for healthy exchange of thoughts. A cultured society can be established with the sharing of one's knowledge with other scholars. It is equally necessary for the professors that they judge the merit of their students without preconceived thoughts. Prof. Vohra failed to admire the new thought of Ryan on 'Screw Jack' system and called it 'fantastic'.

With the help of Prof. Cherian the artist demands that the engineering course ought not to be imposed upon new generation as each student has his/her own interests. Let every student study what he likes. Only then he will succeed in life . Quite often parents impose their likes and dislikes upon their children and generation gap brings horrible results. Then the

father should understand the likes, dislikes and temperament of his young son/daughter. Women of new age are changing fast and aspire for free mixing up with the boys. Precautions are to be taken so that they may not join bad company. Yet some liberty has got to be granted to them. Let them choose their life partner if they want to do so.

In the novel One Night @ Call Center he asserts that students ought to have imagination, intelligence, creativity, self-confidence and patience in times of failures. They have to accept the fact that their plans and research projects may not be approved by the authorities in the first meeting. After all authorities are also responsible to their senior off icers and then the government and it is not easy to take the risk of large amount of money. Due to media the authorities think twice before approving the research project these days. At times they judge its utility in general interest. So, Chetan Bhagat aptly adds importance to research and development. His novel Five Points Someone confirms this fact. He wishes to bring 
Impact Factor: 4.845(SJIF) Research Journal Of English (RJOE) Vol-5, Issue-2, 2020

www.rjoe.org.in An International Peer-Reviewed English Journal

ISSN: 2456-2696

Indexed in: International Citation Indexing (ICI), International Scientific Indexing (ISI), Directory of Research Journal Indexing (DRJI) Google Scholar \& Cosmos.

many social, economic and political changes with the medium of his art.

Chetan Bhagat is great because he paints life on a wide canvas. He paints human nature in real colours and observes differences among people. He confirms that there is unity in diversity in India. Critics admire him for presenting probable people like Hari-Neha, Ryan-Alok, Priyanka-Shyam, Vidya- Govind Patel, Gopal-Aarti, Radhika-Debu, Riya-Madhav, Radhika-Neel Gupta etc. but he does not repeate any one of them second time in the next novel. It is surprising that all these heroines enjoy sex before marriage. But only Priyanka, Aarti and Riya get united with Shyam, Raghav and Madhav. However, they freely take initiative in love making and sex is not a taboo for them. It is remarkable that he has painted new Indian women who wish to get equal rights with men and struggle hard for a decent life. Readers admire him for the fact that he has painted probable events with full details as he does not make them live in any utopian world.

As a realist he has painted many pictures of poverty. People like Alok, Esha, Driver Sahib, Omi, Ishan, Naseer, Ali, Gopal etc. belong to lower strata of life and struggle for existence. Like Ernest Hemingway, he paints the complexities of $21^{\text {st }}$ century society in which it is not easy to understand other members of family, society and the nation. Like V.S. Naipaul, he has painted politicians who adopt corrupt means to earn money and practically cheat the masses. In Five Points Someone he has painted the U.S. President who gets Saddam killed. In Revolution 2020 he has satirized corrupt ways of Shukla ji with the help of truthful reporter Raghav. In The Three Mistakes of My Life he criticizes Australian players who ask Ali to become an Australian cricketer and then play on behalf of Australia. In this novel he satirizes Bittoo Mama and his volunteers for spreading communal hatred in the name of Hinduism.

He chooses the tool of satire carefully and makes the readers acquainted with the gap between fast moving cities and slow moving villages. In Half-girlfriend he gives us an accurate picture of Bihar with broken roads, poor schools and poor children who have no books to read. In a romantic and free mood he uses his brush with colours so as to paint the sexual urges of his characters. And he imitates Emile Zola, Flaubert and D.H. Lawrence. Yet he does not paint highly erotic scenes on sexual desires.

At the same time he mentions the characteristics of Indian culture, Indian civilization, Indian history, Indian art, Indian music, Indian fine arts, Indian modern education system, Indian architecture etc. He boldly raises his voice against the exploitation of poor women, poor labourers, poor students, low paid employees, Indian engineers etc. As an advocate of humanism he speaks in favour of fundamental rights to be granted to all and sundry. Like R.N. Tagore, Dr. Radhakrishnan, Pt. J.L. Nehru etc., he has his own vision of 
Impact Factor: 4.845(SJIF) Research Journal Of English (RJOE) Vol-5, Issue-2, 2020

www.rjoe.org.in An International Peer-Reviewed English Journal

ISSN: 2456-2696

Indexed in: International Citation Indexing (ICI), International Scientific Indexing (ISI), Directory of Research Journal Indexing (DRJI) Google Scholar \& Cosmos.

free India in which equal opportunities are given to all for education, job and success. In his first novel he advocates the fact that everybody should think innovative thoughts and not become slaves of mental debauchery. Through Ryan he asks the students to be creative. Through Riya he asserts the need of learning the art of making speeches. Through Ishan and Ali he asks Indian players to play with full devotion to get gold medals in games and sports. Of course, he regards higher education as one the means of personal success and national progress.

Like R.N. Tagore and R.K. Narayan, Chetan Bhagat wishes to strike against the roots of corruption so that a healthy society may be established in India. As a devotee of omnipotent God he aspires to remove the terrible and shocking poverty of masses with good means. As a citizen of India he wants to share the joys and sorrows of people in happy and sad moments. With his pen he wants to prove fruitful to the young students of country so that they may do good jobs for the nation. As citizens of the nation they will never be treated as slaves because he is an advocate of their fundamental rights. Let their noble deeds prove fruitful for their fellow- beings. So far as the 50 percent poor people of India are concerned Chetan Bhagat writes continuously and proposes many educational and economic plans with his novels. Of course, he does not pretend to be the economic planner or Minister of Finance or Chariman of Niti Aayog and yet proposes solid reform for social reconstruction. Of course, it is his eager desire to eradicate the poverty of people.

So far as problem of poverty is concerned he wants to solve this problem with ethical means. In the novel Five Points Someone he presents the miseries of Alok's family in true colours. Such poor families exist in India in large number and this is a probable situation. Alok's father was an artist and fell down from the roof due to the moving of the supporting poles. His hip-bones had multiple fractures and hence he is unable to work. He can't earn his own bread and hence has become a permanent dependent upon his wife. Alok's mother earns a little salary as a biology teacher. Due to his hard labour Alok qualifies for admission in I.I.T. New Delhi. The real tragedy begins now as he does not have sufficient money to buy new books for himself. Fortunately, he joins the group of Ryan and Hari. But Ryan hails from rich family and can manage scooty for his personal pleasure. Quite often he enjoys outing so as to see films and historical places. The author asserts the Ryan and Hari have real sympathy for Alok. When his father needs medical help urgently, they go to his home and carry his father to the hospital for medical help. Here the author asserts the moral - A friend in need, is a friend indeed. So, Ryan and Hari don't disown the poor friend Alok. But the dark picture of Alok's conduct can't be neglected. Very pertinent questions can be raised against his unethical conduct in 
Impact Factor: 4.845(SJIF) Research Journal Of English (RJOE) Vol-5, Issue-2, 2020

www.rjoe.org.in An International Peer-Reviewed English Journal

ISSN: 2456-2696

Indexed in: International Citation Indexing (ICI), International Scientific Indexing (ISI), Directory of Research Journal Indexing (DRJI) Google Scholar \& Cosmos.

I.I.T. such as - Why does he ignore histudies in I.I.T. as it is not enough to devote merely three hours to studies of a professional course? After a few weeks Ryan forms C2D i.e. control to dominate. They don't want to obey the traditional authorities of I.I.T. and aspire for more liberties which can't be granted at any cost. Why does Alok accept the idea of studying only one hour daily and then play various games such as squash, badminton, scrabble, chess etc.? Why can't he sacrifice his interest in films as he can't afford them? Why does he not think at all while drinking Vodka on the roof of I.I.T. building? What makes him smoke intoxicated cigarettes with his friends? Yet he thinks of the economic problems of his family. Quite often he feels himself sad as there is no money to arrange for the marriage of his young sister. He fails to plan for the proper education of his sister. Ironically he studies in educational institution and yet does not wish to plan for the higher education of his sister to make her independent economically. There is no denying the fact that he fails to gather enough mental strength to raise himself above domestic problems. Just he wishes to get U.S. scholarship for future but fails to work hard for the same. He fails to practice the saying - First deserve and then desire. Due to his half-hearted interest he remains a Five Pointer Only and hence feels guilty at heart.

Yet another important question arises here - Ryan aks Alok and Hari to have original ideas. To him there is dire need of innovative skills in the I.I.T. students and teachers. He asserts that I.I.T. students and teachers must contribute to social welfare schemes and plan to produce things on cheap rates. In other words, he wishes to relate higher studies with research and development. But Alok and Hari enjoy films for pleasure and never prepare any new research project. On the contrary they don't enjoy working for practicals, quiz, assignments etc. Is it not sad? Why does Alok accept the plan of Ryan to steal question paper from Prof. Cherian's office? He must have resisted against this wicked idea. Due to his weak will power he joins Hari and Ryan and ultimately suffers. Then he makes an effort to commit suicide from the roof of I.I.T. building which confirms his cowardice.

As a student Chetan Bhagat studied the $35^{\text {th }}$ song of The Gitanjali and felt impressed with R.N. Tagore's picture of Swaraj. As an ardent lover of national freedom Chetan Bhagat aspires for the atmosphere in which all young students of all sections of society get education without any considerations of caste, colour and creed. Let the citizens lead a life of dignity without any fear of colonial powers. He wants that the gates of knowledge should be open to students in all the states. As 'domestic walls' prove to be the greatest hurdles, he wishes to break them without any hesitation. Why should there be differences in the name of regionalism and communalism? Let the scholars write books on new subjects and seek new 
Impact Factor: 4.845(SJIF) Research Journal Of English (RJOE) Vol-5, Issue-2, 2020

www.rjoe.org.in An International Peer-Reviewed English Journal

ISSN: 2456-2696

Indexed in: International Citation Indexing (ICI), International Scientific Indexing (ISI), Directory of Research Journal Indexing (DRJI) Google Scholar \& Cosmos.

knowledge. After all India has her glorious past of more than 5000 years and a lot of ancient classics to be proud of. Let the present generation of people study the lofty thoughts from sublime books to elevate themselves morally and culturally. Of course they have to forget their tiredness, fatigue and indolence to understand the practical side of thoughts. Tagore is not ready to compromise with any ism or theory as he is supporter of 'perfection'.

Tagore further says that there are many hurdles in the path of progress and development and the people have to cross them. In 1913 he noticed that imperialism and colonization imposed many restrictions upon the people of colonies of Africa and Asia. Let the 'dreary desert' blossom once again as Indian culture had been dormant for a few centuries due to so many invaders who came here from all the four sides. If God blesses his country men and women, they will rise again to create fearless society 'ever widening thought and action'. (S

35) He has no doubt about the bright future of India and hopes to see 'heaven of freedom' soon as the freedom fighters had organized themselves under the banner of National Congress. Many eminent politicians had seen the free atmosphere of Europe where people enjoyed the benefits of fundamental rights and impartial judiciary. Same is the hope of Chetan Bhagat today when he writes his ninth novel. The above feelings guided him to write What Young India Wants and India Positive.

In the essay Of Truth Francis Bacon explains the first reality of creation of i.e. God created light to remove the darkness of earth and then granted the light of reason to human beings. Chetan Bhagat is highly conscious of this intellectual light and makes regular use of this sense of reason while writing his novels. In Five Points Someone he differentiates between Ryan and Alok, between Neha and Hari, between Prof. Veera and Prof. Cherian, between the parents of Alok and the parents of Ryan, between Prof. Cherian and his son Samir etc. and asks the readers to analyze differences between man and man. All have different physical and intellectual capabilities and don't think beyond that. While painting such differences within society and family he imitates Henrik Ibsen and G.B. Shaw who wrote problem plays on society blaming it for man's sufferings. Similarly he differentiates between Shyam and Vroom, between Bakshi and Vroom, between Esha and Radhika, between Radhika and Priyanka, between the Boss and the employees, between ethical people and corrupt people, between atheists and theists etc. But the major difference is between the unemployed people and the employed people. Vroom is highly worried when he thinks of his future as an unemployed young man because the number of calls is decreasing in this call center. 
Impact Factor: 4.845(SJIF) Research Journal Of English (RJOE) Vol-5, Issue-2, 2020

www.rjoe.org.in An International Peer-Reviewed English Journal

ISSN: 2456-2696

Indexed in: International Citation Indexing (ICI), International Scientific Indexing (ISI), Directory of Research Journal Indexing (DRJI) Google Scholar \& Cosmos.

In Positive Psychology C.R. Synder and Shane J. Lopez analyze the characteristics of the people having positive approach to life and assert the value of virtue creaticity, hope, knowledge, wisdom, curiosity, open-mindedness, love of learning, broad perspective, courage, challenging mood, persistence, integrity, humanitarian approach, kindness, social intelligence, sense of justice, leadership, temperance, humility, prudence, self-control, capacity to appreciate beauty and excellence, sense of elevation, gratitude, hope, purposefulness, vitality' etc. (PP 18-22) Men of hope surpass hurdles as mental illness, negative thoughts, nervousness, sense of degeneration etc. They try to create opportunities for mental enlightenment. For example, the industrial revolution of $19^{\text {th }}$ century created new wonderful opportunities for the rich people and they established a lot of machines to convert matter into matter. As a result they earned huge profits with the capturing of foreign markets of Asia and Africa. On then contrary the conditions of labourers became further miserable as they had to work harder than before and could not get bonus and other facilities in time of sickness, old age and break- downs in the industries. Yet the industrialists of positive mentality faced all problems and continued to establish new industries even outside England for more and more profits.

There is no limit to the agony of Alok, Hari and Ryan after their one semester is suspended by DISCO. Yet Prof. Veera encourages them to work regularly in his lab on Ryan's research project of lubrication. Due to their hope they work hard under the supervision of worthy Professor and their experiments bring remarkable results. Within four months the results are approved by Prof. Veera, Prof. Cherian, Prof. Vohra and the Dean. They appreciate the outcome of the experiment and compensate their attendance and classes of the suspended semester and finally allow them to appear at the final exam. that year. Here Chetan Bhagat shows the victory of hope, perseverance and hard work against conspiracy, theft, carelessness and indiscipline.

Towards the end of the novel One Night@ Call Center the situation is extremely gloomy as all of them expect the closure of the call center soon. Secondly, Priyanka feels cheated by Ganesh and decides not to marry him. Thirdly, Esha has been cunningly seduced by the famous fashion designer and she fails to accept the money sent to her as compensation for the loss of chastity. Fourthly, Major uncle gets a letter from his son not to misguide his grandson. And Boss Bakshi is confused due to rebellious approach of Vroom. Shyam is also in a gloomy mood due to his breakup with Priyanka. Lastly, the car get stuck on the top of a pit 50 feet deep and they will fall into it if the car loses its balance. In such gloomy situation the mobile network does not work. But Omniscient God appears at such a critical juncture and saves them in no time. Divine network works when all hopes 
Impact Factor: 4.845(SJIF) Research Journal Of English (RJOE) Vol-5, Issue-2, 2020

www.rjoe.org.in An International Peer-Reviewed English Journal

ISSN: 2456-2696

Indexed in: International Citation Indexing (ICI), International Scientific Indexing (ISI), Directory of Research Journal Indexing (DRJI) Google Scholar \& Cosmos.

are dashed to the ground. And the artist Chetan Bhagat accepts the same.

With his novels Chetan Bhagat confirms Matthew Arnold's theory - 'If work of art shows indifference towards ethical values, it will result in having indifference towards life. The artist can't afford to revolt against ethical values in any situation. In The Acknowledgement to The Three Mistakes of My Life the author admits. God who continues to bokafter me despite my flaws'. (3ML X)

In The Prologue to this novel he asserts that courageous and positive people accept the challenges of life at every time and remarks : Life is tough when you are always talking to people smarter than you. (3ML xiv)

Due to his noble mission of life he declares through Govind Patel : 'Life became good'. (3ML 10) As he started tuitions of Maths. and got some fees with that '. The artist confirms : 'God helps those who help themselves. As Govind's financial position improves, he earns respect in society too. After few months cheerfulness revives and he starts enjoying business as well as teaching Maths. As he thinks of future, he plans to buy a shop in the up-coming Mall so that his businesses may prosper further - Why to be a victim dstagnation? He tells Omi and Ishan : 'If you don't grow in business, you stagnate'. (3ML 25)

In the $4^{\text {th }}$ chapter of The Three Mistakes of My Life the author refers to moral values as asserted by Hindu scriptures, the values that have stood the tests of time and place. Parekh ji advocates in the presence of Hindus :

'Our scriptures tell us not to harm others. They teach us the acceptance of all faiths, even if those faith do not accept us. They teach us patience. Thousands of years ago, our wise men thought of such wonderful values, valid even today. And today you great men pass on these values to society'. (3ML 42)

Here Chetan Bhagat's positive ethical approach is fully valid and justified as 'faith' and 'patience' are two solid positive virtues propagated by saint Vashishtha, Parshuram, Vishawamitra etc. to their followers. Then Parekh ji calls himself 'a servant of God'. (3ML 43) According to scriptures, all devotees are servant of God and like John Milton, remain ready to obey His orders round the clock. Then Parekh ji criticizes people who follow hypocrisy to achieve their goals:

We won't stand for hypocrisy or unfairness. That is why, we don't elect the pseudo-secular parties. (3ML 44)The above statement of Parekh ji confirms Chetan Bhagat's hateful attitude towards negative activities. He appreciates Prof. Naseer's statement: 'India is free country'. (3ML 69) 
Impact Factor: 4.845(SJIF) Research Journal Of English (RJOE) Vol-5, Issue-2, 2020

www.rjoe.org.in An International Peer-Reviewed English Journal

ISSN: 2456-2696

Indexed in: International Citation Indexing (ICI), International Scientific Indexing (ISI), Directory of Research Journal Indexing (DRJI) Google Scholar \& Cosmos.

This statement is absolutely true because fundamental rights have been granted to all citizens. All political parties can contest elections to be held after every five years. People have the freedom to join any political party. If their rights are attacked by anybody, they can seek the help of the courts. The citizens can cast their votes to the candidates of their choice. Then he refers to Muslim tensions and asserts the importance of existing harmony between the two communities :Yes, male Chimpanzees of the same pack fight violently with each other - for food, females, whatever. 'However, after the fight, they go through a strange ritual. They kiss each other, on the lips'. (3ML 71)

Towards the end of $7^{\text {th }}$ chapter of this novel the author refers to Pandit Giriraj's faith in God. Govind remarks .His God made him pay a big price in life, but he still felt grateful to him. I could never understand this absolute faith that believers possess. (3ML 92)In the beginning of $8^{\text {th }}$ chapter the author admires 'Ali's self-control' as he never loses his wisdom inspite of poverty, and physical weakness, his religion, lack of money etc. Towards the end of the novel Ali gets full support from Ishan and ultimately becomes a successful cricketer.

When Govind is sad due to the collapse of the new Mall building, Vidya gives him moral support:

... Sometimes life throws curve balls and you question why

There may be no answers, but I assure time will heal the wound .. (3ML 112)

After getting solace from Vidya, Govind accepts : 'Life goes on' (3ML 113) and becomes busy in the daily routine of life.

Virginia Woolf, the great psychological novelist of $20^{\text {th }}$ century attached importance to 'impressions' that come to the mind of characters every time. She records these 'impressions' though they come from all sides. When there is chaos and formlessness, she selects the relevant impressions and develops the the me of the novel with their help. She asked every artist to 'look within' to find out the reality. Actually she failed to accept the realistic approach of Henry Fielding, Charles Dickens, Jane Austen etc. as she is intimately connected with conscious, subconscious and unconscious mind of the characters i.e. what do they think in moments of tension, frustration, dementia, depression, joy, delight etc.? Her novels follow the methods of James Joyce, Henry James, Dorothy Richardson etc. and concentrate upon the technique of stream of consciousness novel. She aptly says that same impressions do not come on Monday, then Tuesday and then Thursday and so on. For example her novel Mrs. Clarrisa deals with the life of a single day when Clarrisa thinks of her past friends, her husband Richard Dalloway who is going to be a cabinet minister the same evening. (ROO 40) 
Impact Factor: 4.845(SJIF) Research Journal Of English (RJOE) Vol-5, Issue-2, 2020

www.rjoe.org.in An International Peer-Reviewed English Journal

ISSN: 2456-2696

Indexed in: International Citation Indexing (ICI), International Scientific Indexing (ISI), Directory of Research Journal Indexing (DRJI) Google Scholar \& Cosmos.

Chetan Bhagat follows the technique of stream of consciousness novel to a great extent and tries to probe into the subconscious mind and unconscious mind of Hari, Ryan, Alok, Neha, Priyanka, Shyam, Vroom, Vidya, Govind Patel, Ishan, Omi, Gopal, Aarti, Raghav, Ananya, Krish, Madhav,Riya, Radhika, Debu, Neel Gupta etc. and this is the reason that these above mentioned people appear life-like. He inspires the readers to analyze the conscious mind of his characters and then relate them with their impressions coming from subconscious and unconsciousness mind. For example, he analyzes Ryan's impressions about I.I.T., Venkat, Alok, Hari, Neha, Prof. Vohra, Prof. Cherian, his own parents etc. In One Night @ Call Center he analyzes the psychology of Shyam regarding his past when he enjoyed dating five times with Priyanka in the Coffee-Houses of New Delhi. What are impressions of Vroom about Boss Bakshi? What does he think of life as a whole? What does he think of Esha? In The Three Mistakes of My Life the author reveals the personality of Vidya, Govind Patel, Ishan, Omi, Ali etc. through the conscious mind of Govind - What does he think of his father? How does he admire his hard working mother? How does he feel guilty after having enjoyed sex nine times with Vidya? What does he think of the Austrian cricketers? What are his impressions about the systemic life of Australians in Sydney? etc. In One Indian Girl he analyzes the subconscious mind of Radhika, Debu, Neel Gupta, Brijesh, Mom of Radhika etc. in moments of frustration. The ego of Radhika is responsible for her tensions and she has no loving affection for her sister Aditi as the latter is physically beautiful. In 2 States Ananya's spersonality has been revealed with the impressions that come to the mind of Krish. Similarly Krish reveals the quarrel between his parents with his impressions. Ananya shares her impressions about I.I.T.ians with Krish in the beginning of the novel. Thus, the novels of Chetan Bhagat answer the question

How to be successful in life? Each novel has been developed on a particular positive idea. It means that his novels are a healthy guide for everybody's life. As a democrat he supports the merits of democracy and yet does not fail to expose its demerits. As a supporter of Indian culture, he elaborates its characteristics so that people may follow them for a cultured life. As a supporter of socialism he advocates that equal chances should be given to all for progress. Regarding Indian economy he reveals its demerits and yet hopes for social reconstruction and economic regeneration if new methods of investment are adopted. Thus, the novels of Chetan Bhagat answer the question

How to be successful in life? Each novel has ben developed on a particular positive idea. It means that his novels are a healthy guide for everybody's life. As a democrat he supports the merits of democracy and yet does not fail to expose its 
Impact Factor: 4.845(SJIF) Research Journal Of English (RJOE) Vol-5, Issue-2, 2020

www.rjoe.org.in An International Peer-Reviewed English Journal

ISSN: 2456-2696

Indexed in: International Citation Indexing (ICI), International Scientific Indexing (ISI), Directory of Research Journal Indexing (DRJI) Google Scholar \& Cosmos.

demerits. As a supporter of Indian culture, he elaborates its characteristics so that people may follow them for a cultured life. As a supporter of socialism he advocates that equal chances should be given to all for progress. Regarding Indian economy he reveals its demerits and yet hopes for social reconstruction and economic regeneration if new methods of investment are adopted.

\section{References:}

- Bhagat, Chetan Five Points Someone New Delhi : Rupa Publications 2004.

- One Night @ Call Center New Delhi : RPublications 2005.

- The Three Mistakes of My Life New Delhi : PPublications 2008.

- 2 States New Delhi : Rupa Publications 2009.

- Half-girlfriend New Delhi : Rupa Publications2009.

- Revolution 2020 New Delhi : Rupa Publications2011.

- One Indian Girl New Delhi : Rupa Publications2016.

- What Young India Wants New Delhi : Rupa Publications 2012.

- India Positive Seattle : Wastland 2019.

- Synder, C.R. \& Lopez, Shaney J. Positive Psychology New Delhi : Sage Publications 2007.

- Tagore, R.N. Gitanjali Bareilly : Prakash Book Depot 2007.

- Woolf, Virginia A Room of One's Own Victoria : Penguin 1963. 